Virginia Commonwealth University VCU Scholars Compass

2009

\title{
Life-Centered Ethics and the Human Future in Space
}

Michael Noah Mautner

Virginia Commonwealth University, mmautner@vcu.edu

Follow this and additional works at: http://scholarscompass.vcu.edu/chem_pubs

Part of the Biology Commons, Ecology and Evolutionary Biology Commons, and the Social and Behavioral Sciences Commons

(C) 2008 The Author. Journal compilation (C) 2008 Blackwell Publishing Ltd.

\section{Downloaded from}

http://scholarscompass.vcu.edu/chem_pubs/77

This Article is brought to you for free and open access by the Dept. of Chemistry at VCU Scholars Compass. It has been accepted for inclusion in Chemistry Publications by an authorized administrator of VCU Scholars Compass. For more information, please contact libcompass@vcu.edu. 


\title{
ARTICLES
}

\section{LIFE-CENTERED ETHICS, AND THE HUMAN FUTURE IN SPACE}

\author{
MICHAEL N. MAUTNER
}

\section{Keywords}

bioethics,

life-centered ethics,

biotic ethics,

panbiotic ethics,

genetic engineering,

biophilia,

life in space,

astroethics

\begin{abstract}
In the future, human destiny may depend on our ethics. In particular, biotechnology and expansion in space can transform life, raising profound questions. Guidance may be found in Life-centered ethics, as biotic ethics that value the basic patterns of organic gene/protein life, and as panbiotic ethics that always seek to expand life. These life-centered principles can be based on scientific insights into the unique place of life in nature, and the biological unity of all life. Belonging to life then implies a human purpose: to safeguard and propagate life. Expansion in space will advance this purpose but will also raise basic questions. Should we expand all life or only intelligent life? Should we aim to create populations of trillions? Should we seed other solar systems? How far can we change but still preserve the human species, and life itself? The future of all life may be in our hands, and it can depend on our guiding ethics whether life will fulfil its full potentials. Given such profound powers, life-centered ethics can best secure future generations. Our descendants may then understand nature more deeply, and seek to extend life indefinitely. In that future, our human existence can find a cosmic purpose.
\end{abstract}

\section{INTRODUCTION}

Biotechnology can transform life extensively, especially in the new environments of space. These developments will raise profound questions in bioethics and space ethics. Life-centered (biocentric) principles can provide guidance. These ethics can be generalized as biotic ethics, which value organic gene/protein life itself, and as panbiotic ethics, which seek to expand our family of organic life in the universe.

Expansion in space may be in fact imperative for our future. In contrast to fragile and limited Life on Earth, multiple worlds in space can secure our survival, and provide rich resources. ${ }^{1}$

\footnotetext{
${ }^{1}$ N.A. Rynin. K. E. Tsiolkovskii: Life, Writings, and Rockets. Leningrad, 1971. (Vol. 3, No. 7 of Interplanetary Flight and Communication. Leningrad Academy of Sciences of the USSR. Translated by the Israel Program for Scientific Translations, Jerusalem). 'The Earth is the cradle of the human mind, but one cannot live in the cradle forever'. A. Starchild. 2000. Science Fiction of Konstantin Tsiolkovsky. New York, NY: International Specialized Books Services; F. Dyson. 1979. Time Without End: Physics and Biology in an Open Universe. Rev. Modern
}

Address for correspondence: Michael Mautner, Department of Chemistry, Virginia Commonwealth University, Richmond, VA 23284-2006, Telephone: (240) 423-6278. E-mail: mmautner@vcu.edu,www.astro-ecology.com 
These visions are developing into concrete programs. ${ }^{2}$ For example, large-scale space colonies, ${ }^{3}$ and the terraforming of Mars, ${ }^{4}$ are studied. Seeding new solar systems deeper in space with life was proposed, ${ }^{5}$ motivated by life-expanding panbiotic ethics. ${ }^{6}$ Adapting life to these new environments can affect the future of evolution. ${ }^{?}$

The potentials for life in space are supported by experimental astro-ecology. ${ }^{8}$ Plant cultures on meteorite/ asteroid materials suggest that the Solar System can support populations of trillions. ${ }^{9}$ These resources can make territorial conflicts obsolete, assure human survival, and increase biological and cultural diversity.

Life in space opens ethical and philosophical questions that have been discussed starting with Tsiolkovski, ${ }^{10}$ and

Phys. 1979; 51: 447-468; F. Dyson. 1988. Infinite in All Directions. New York, NY: Harper and Row.

${ }^{2}$ S. O'Keefe, NASA Administrator. Pioneering the Future. 'To improve life here, to extend life to there, to find life beyond'. April 12, 2002. Syracuse University. Similar programs were announced by the European Space Agency, India, China, and Japan.

${ }^{3}$ G.K. O'Neill. The Colonization of Space. Physics Today 1974; 27 : 32-38; G.K. O’Neill. 1977. The High Frontier. New York, NY: William Morrow.

${ }^{4}$ M.J. Fogg. Terraforming: A Review for Environmentalists. The Environmentalist 1993; 13: 7-12.

${ }^{5}$ M.N. Mautner. 2000. Seeding the Universe with Life: Securing Our Cosmological Future. Washington, DC.: Legacy Books. (www.panspermia-society.com)

${ }^{6}$ M.N. Mautner \& G.L. Matloff. Directed Panspermia: A Technical Evaluation of Seeding Nearby Solar Systems. Bull. Astr. Soc. 1977; 9; 501 and J. British Interplanetary Soc. 1979; 32: 419-424; M.N. Mautner. Directed Panspermia. 2. Technological Advances Toward Seeding Other Solar Systems, and the Foundations of Panbiotic Ethics. $J$. British Interplanetary Soc. 1995; 48: 435-440; Directed Panspermia. 3. Strategies and Motivations for Seeding Star-Forming Clouds. J. British Interplanetary Soc. 1997; 50: 93-98. www.panspermia-society.com

7 A. Rosenfeld. 1975. The Second Genesis: The Coming Control of Life. New York, NY: Vintage Books: 281; A.C. Clark. 1984. Profiles of the Future. New York, NY: Warner Books; 210; M.H. Hart. 1985. Interstellar Migration, the Biological Revolution, and the Future of the Galaxy. In Interstellar Migration and Human Experience, B.R. Finney \& E.M. Jones, eds. Berkeley, CA: University of California Press: 278291. Ethical aspects of evolution in space are also discussed in M.A.G. Michaud. 2007. Contatct with Alien Civilisations. New York, NY: Copernicus Books.

${ }^{8}$ M. N. Mautner. Biological Potential of Extraterrestrial Materials. 1. Nutrients in Carbonaceous Meteorites, and Effects on Biological Growth. Planetary and Space Science. 1997; 45: 653-664; Planetary Resources and Astroecology. Planetary Microcosm Models of Asteroid and Meteorite Interiors. Implications for Space Populations and Panspermia. Astrobiology 2002; 2: 59-76; M.N. Mautner. Directed Panspermia, Astroethics, and our Cosmological Future. Int. J. Astrobiology 2004; Supplement 1: 116 (www.Astro-Ecology.com)

${ }^{9}$ M.N. Mautner. Life in the Cosmological Future: Resources, Biomass and Populations. J. British Interplanetary Soc. 2005; 58: 167-180.

${ }^{10}$ Tsiolkovski, op. cit. note 1. addressed more recently in several books. ${ }^{11}$ In parallel, biocentric ethics are also advancing. Life-centered principles have been established since antiquity, as in the edict 'choose life', ${ }^{12}$ and in Buddhist principles, ${ }^{13}$ and they are receiving new attention by environmental ethics. ${ }^{14}$

Space ethics and biocentric ethics are both at early stages. They are usually considered separately, although a connection was suggested for seeding other solar systems with life, motivated by life-centered principles. ${ }^{15}$ This paper will propose further basic connections between life-centred ethics and space ethics.

Space adaptation through designed evolution may affect the future profoundly, especially when our designs become self-fulfilling. Our survival can then be secured only if it is pursued deliberately. In that future our guiding ethics can have far-reaching consequences.

This paper intends to contribute to a discourse on lifecentered astroethics and on its effects on the future. In particular, it will postulate that expansion in space, combined with life-centered ethics, can best secure our longterm survival.

\section{SCIENCE-BASED ARGUMENTS FOR BIOCENTRIC ETHICS}

Before biocentric ethics are applied to space, these lifecentred principles need to be justified rationally. Of course all ethics are subjective, but scientific insights can provide rational foundations.

Molecular biology shows that all organic cellular life share a common feature, self-reproduction through gene/

${ }^{11}$ E.C. Hargrove, ed. 1986. Beyond Spaceship Earth - Environment Ethics and the Solar System. Sierra Club Books; P.C.W. Davies. 1995. Are We Alone? Philosophical Implications of the Discovery of Extraterrestrial Life. London: Basic Books; B.R. Finney. 1985. Voyagers Into Ocean Space. In Interstellar Migration and Human Experience. B. R. Finney \& E. M. Jones, eds. Berkeley: CA: University of California Press: $164-180$.

${ }^{12}$ Bible. Old Testament Deuteronomy: ch. 30 vv. 15, 19.

13 A. Hunt-Badiner, ed. 1990. Dharma Gaia: A Harvest of Essays in Buddhism and Ecology. Berkeley, CA: Parallax; B. Gruzalski. Gandhi's Contribution to Environmental Thought and Action. Environmental Ethics 2002; 24: 227-242.

14 A. Schweitzer. 1990. Out of My Life and Thought. New York, NY: Holt: 131. '(being good:) to preserve life, to promote life, to raise to its highest value life which is capable of development'; P.W. Taylor. 1986. Respect for Nature: A Theory of Environmental Ethics. Princeton, NJ: Princeton University Press: 45; J.R. Des Jardins. 1997. Environmental Ethics: An Introduction to Environmental Philosophy. Belmont: Wadsworth. G.E. Moore. 1988. Principia Ethica. NY: Prometheus Books. 'With regard to some rules.... where the instincts to preserve and propagate life were strong. ...'

${ }^{15}$ Mautner, op. cit. note 5; Mautner \& Matloff, op. cit. note 6. 
protein cycles. Biotic ethics value these core patterns of biology themselves, and strive to perpetuate them. Expansion in space can broaden these principles into panbiotic ethics that value all organic cellular gene/ protein life, present and future, and seek to maximize life in all accessible habitats.

Although these ethics value all cellular gene/protein life, from a human point of view life may best enjoy conscious existence, further motivating self-propagation.

\section{Molecular self-replication and the definition of life}

When seeking to define Life, we ask: What objects in Nature are we willing to accept as fellow living beings? In this sense, 'what is Life?' is a question of judgement, rather than of science. However, science can reveal common features that help define fellow life.

Most definitions of life recognize reproduction and evolution as essential features. Of all known phenomena, only organic biological life reproduces actively, and evolves. A plausible definition may then state: 'Life is a process whose outcome is the self-reproduction of complex molecular patterns'. Importantly, Life is then a process that requires a constant flow of information, matter and energy.

More specifically, biological matter is composed of genetic information contained in DNA sequences that code proteins, which in turn help reproducing the DNA sequences. All organic cellular life uses these selfreproducing gene/protein cycles.

\section{The unique position of life in nature}

Complexity assigns a unique position to life. Proteins, DNA and membranes are all made of complex molecules that are structured precisely for their functions. Complex enzymes catalyze specific reactions, and complex t-RNA molecules convert DNA codes to amino acids in proteins. Even the most simple cell possesses thousands of finely tuned complex molecules that act in coordination. This complexity is unique to life.

Biology also depends on the precise coincidence of seemingly independent physical laws. ${ }^{16}$ The universe contains just enough matter and energy to avoid fast collapse

\footnotetext{
${ }^{16}$ L.J. Henderson. 1970. The Fitness of the Environment. Glouster: Peter Smith: 312. J. Gribbin \& M. Rees. 1989. Cosmic Coincidences. New York, NY: Bantam Books: 269; F. Hoyle. 1983. The Intelligent Universe. London: Michael Joseph: 218; P.C.W. Davies. 2007. Cosmic Jackpot: Why Our Universe Is Just Right for Life. New York, NY: Houghton Mifflin.
}

or expansion, allowing liveable conditions for eons. Stars such as the Sun last for billions of years and host habitable planets, due to a coincidence of the laws of gravity, nuclear physics, gas convection, and magnetic fields. Biology is based on carbon, formed in stars due to coincidental nuclear resonances. Electromagnetism bonds molecules with just the right strength, allowing chemistry and biology to exist.

Life therefore depends on the laws of gravity, nuclear forces, chemistry, thermodynamics and cosmology. These laws are seemingly independent of each other, but they coincide precisely to allow life to exist. In this sense, the physical universe itself comes to a unique point in life.

\section{The unity of life}

We have a special feeling for other living beings, an empathy called 'biophilia'. ${ }^{17}$ This special relation exists even among very different life-forms. For example, we readily recognize a cactus being closer to us than a rock. We also recognize microorganisms as fellow life, and astrobiology searches for microorganisms in space to ease our cosmic loneliness. We sense that all living beings are one family who share mutual affinity and dependence.

This sense of unity is supported by science. From microorganisms to humans, we all share common designs. Every living cell is surrounded by selective membranes; processes energy through biochemical cycles using enzymes and ATP; has a complex genome coded in DNA sequences; and uses a common code and mechanism for translating three-letter DNA codes to amino acids in proteins. Ultimately, the proteins help to reproduce the DNA code, completing the gene/protein cycle. ${ }^{18}$

Further, phylogenetic trees indicate that all terrestrial life can be traced to a common ancestor. ${ }^{19}$ Organisms as different from us as yeasts share half; mice, over $90 \%$, chimpanzees, over $95 \%$, and different human individuals share over $99 \%$ of our genome. ${ }^{20}$

These scientific insights give a deeper meaning to the unity of all Life. Our complex molecular patterns are common to all organic gene/protein life and distinguish us from any other phenomena of nature.

\footnotetext{
${ }^{17}$ E.O. Wilson \& S. McVay, eds. 1993. The Biophilia Hypothesis. Washington, DC: Island Press.

18 W.K. Purves et al. 2001. Life: The Science of Biology. Sunderland, MA: Worth Publishers, Inc.

${ }^{19}$ S.L. Baldauf, J.D. Palmer \& W.F. Doolittle. The Root of the Universal Tree and the Origin of Eukaryotes Based on Elongation Factor Phylogeny. Proc. Nat. Academy Sci. USA 1996; 93: 7749-7754.

20 A. Gibbons. Which of Our Genes Make Us Humans. Science 1998; 81: $1432-1434$.
} 


\section{Observational equivalence, and life and purpose}

Expanding life in space will require action with purpose. 'The purpose of life' has been pondered since antiquity, but today it can be examined with scientific insights. One useful principle is 'observational equivalence': If two phenomena are identical in all observables, then they are identical in fact. Examples are the relativistic equivalence of gravity and acceleration, and Turing's test of intelligence. $^{21}$

Applied to behaviour, self-perpetuation is usually included in the definition of life. All organisms act for survival and propagation, as if they pursued these outcomes deliberately. This of course does not imply conscious planning. However, if the observed behavior of organisms appears to pursue survival and propagation, then the equivalent effective observable purpose of life is survival and propagation. Therefore life may be seen to have an intrinsic purpose, and since the universe contains life, it contains purpose. In brief, the purpose of life is to live.

We, as living beings, share this effective purpose. The shared drive for self-propagation can then define a human purpose: to safeguard and perpetuate life. To this effect, we can expand life and seek to advance it into a controlling force in nature. These objectives can give human existence a cosmic purpose.

From a subjective point of view as conscious humans, we may wish to maximize conscious life. In fact, the conscious enjoyment of life can further motivate selfcontinuation.

In summary, life is united by its unique complexity, by the physical laws that precisely allow life, and by selfreproduction through gene/protein cycles. Life also has a special value for us as living beings. Therefore both objective science and our subjective judgement can support life-centered ethics and its purpose to propagate life.

\section{SPACE BIOETHICS: PROSPECTS AND QUESTIONS}

\section{Astro-ethics and survival in a controlled future}

In space, life can access limitless resources through astronomical times, helped by designed evolution in new environments. With such mastery of nature, our objectives become self-fulfilling.

${ }^{21}$ S. Goldberg. 1984. Understanding Relativity: Origin and Impact of a Scientific Revolution. Cambridge, MA: Birkhauser; A. Turing. Computing Machinery and Intelligence. Mind 1950; 256: 433-460.
With biotechnology that adapts us to space we can also control our biological future. However, these powers also entail dangers. In particular, tests by survival will always apply, both in natural and in designed evolution. Fit life-forms will survive, while failed designs will perish. This logic of life has guided, and will continue to guide, evolution. These tests of survival must be taken into account when designing future life.

In a designed future, what we pursue, we shall accomplish. Therefore, to prevail, survival must be pursued deliberately. This pursuit can be secured by ethics that aim to propagate life. Therefore, life-centered ethics themselves must be always propagated to secure our continued survival.

Ultimately it may depend on our ethics whether life will realize its cosmic potentials.

\section{Astro-ecology and space populations. Should we create populations of trillions?}

Life-centered ethics suggest that we should use space to advance life, and panbiotic ethics suggest that we should use space to maximize life. Of course, the quality of future life also matters, and in particular, we may wish to maximize conscious life.

Quantitatively, we may wish to maximize life over specific, maybe astronomically long, times. We can define a possible measure of the amounts of life in terms of biomass summed over of the time that it exists (Biomass Integrated Over Times Available (BIOTA) measured in kg-years). ${ }^{22}$

The potential amount of life in the Solar System can be estimated based on the available resources, such as the carbonaceous asteroids and comets that contain water, organic carbon and mineral nutrients. These resources can support, at high standards, human populations of thousands of trillions, more than one hundred thousand times the Earth's present population. ${ }^{23}$ Cometary resources can yield biomass a hundred times larger; and a

\footnotetext{
${ }^{22}$ In mathematical terms, the objective is to maximize the term BIOTA (Biomass Integrated Over Time Available), defined as the integral of $\mathrm{B}(\mathrm{t}) \mathrm{dt}$, where $\mathrm{B}(\mathrm{t})$ is total biomass as a function of time and the integration is over the habitable lifetime of the universe. The ultimate maximum would be achieved by converting all matter to biomass and maximizing its longevity. (Mautner, op. cit. note 9)

${ }^{23}$ The $1 \mathrm{e} 22 \mathrm{~kg}$ carbonaceous asteroids contain $2 \%$ carbon, $10 \%$ water, and phosphorus and nitrogen, the limiting element. This could yield a human biomass of $3 \mathrm{e} 20 \mathrm{~kg}$ (exponential notation, $3 \mathrm{e} 20=3 \times 10^{20}$ ) in a population of 6e18, a hundred million present Earth populations. Alternatively these resources can yield $6 \mathrm{e} 20 \mathrm{~kg}$ general biomass, and if $100,000 \mathrm{~kg}$ biomass supports one human, the population in the Solar System would be $6 \mathrm{e} 15$ (six thousand trillion) humans, equal to about 100,000 present Earth populations.
} 
population equal to that of one million Earths. Extended to the galaxy, if one in ten stars has habitable environments, the above immense amounts can be multiplied further by ten billion.

Should we aim to create such immense amounts of life in billions of solar systems? Panbiotic ethics that seek to maximize life support these objectives. Further, this expansion will allow new lines of evolution, rich biodiversity, and ever advancing civilizations.

The potential time-scales of future life are also astronomical. For example, the expected lifetime of the Solar System is five billion years, while star-bound civilizations may exist for hundreds of trillions of years. ${ }^{24}$ With these data, we can calculate the immense amounts of timeintegrated BIOTA that resources in the Solar System permit. $^{25}$

These immense populations may be created relatively rapidly, but biological wastage could exhaust life in the Solar System in half a million years. On the other hand, smaller but still very large populations could last through five billion future years of the Sun.

Should we construct immense shorter-lived populations or smaller but longer-lived populations? It would seem preferable that life should exist as long as possible.

\section{The ultimate prospects. Should we propagate} life if the future is finite?

Considering the amounts of matter in the universe and its duration in time, we can estimate the ultimate amounts of possible life in the universe.

If all matter was converted to biomass, some of it would have to be then converted to energy to sustain biology. On this basis, we can calculate the ultimate extent of possible life in the galaxy and in the universe, in the form of populations of trillions that last trillions of eons. ${ }^{26}$ This potential scope of life is indeed immense, but by current cosmology, still finite.

\footnotetext{
${ }^{24}$ F. Adams \& G. Laughlin. 1999. The Five Ages of the Universe. New York, NY: Touchstone.

${ }^{25}$ With $6 \mathrm{e} 20 \mathrm{~kg}$ asteroid-based biomass, in the five billion future years of the Sun the time-integrated biomass (BIOTA) in the Solar System will be $3 \mathrm{e} 30 \mathrm{~kg}$-years. Cometary resources can yield a biomass still a hundred times larger. (Mautner, op. cit. note 9).

${ }^{26}$ The estimated $1 \mathrm{e} 41 \mathrm{~kg}$ baryonic matter in the galaxy can be converted gradually to biomass and then to energy, sustaining a steadystate biomass of $3 \mathrm{e} 11 \mathrm{~kg}$, possibly as ten billion humans, comparable to the current world population. In this manner life would last for an incomprehensible 1e37 years until protons decay, yielding BIOTA of $3 \mathrm{e} 48 \mathrm{~kg}$-years. For life in the universe these numbers may be multiplied by one hundred billion galaxies, allowing a time-integrated biomass of 3 e59 kg-years of biological life in the universe. (Mautner, op. cit. note 9)
}

Is there a point to maximizing life if it is finite? Panbiotic ethics that seeks to maximize life would answer in the affirmative. The vast scope of future life will allow great biological diversity, and rich experiences for intelligent beings. These potentials can further encourage us to secure and expand life.

Is the duration of life in the universe really finite? Cosmology will be controlled by dark matter and dark energy, both of whose natures are unknown. We have evidence about the past fourteen billion years since the Big Bang, but this is fleetingly short compared with trillions of future eons. Our descendants may have to observe cosmology for many eons until they can predict, and maybe control, the ultimate future.

For now, we need to secure Life for future generations. They may then understand Nature more deeply, and seek to extend life indefinitely.

\section{Seeding other solar systems with life}

We can soon start expanding life by seeding other solar systems. Human travel to other stars has major obstacles, ${ }^{27}$ but we can soon start directed panspermia, sending microorganisms to other solar systems to plant the essential patterns of gene/protein life. We can also include eukaryotic organisms, hardy plant spores and the cysts of microscopic animals to start higher evolution. ${ }^{28}$

Solar sails or seeded comets can launch microbial capsules to nearby stars, or to clusters of new stars in interstellar clouds where they can seed many new solar systems. ${ }^{29}$ Some of this new life may evolve into civilizations that can promote Life further in the galaxy.

These directed panspermia missions will be launched easily from space colonies, even by individuals or small groups. Should we proceed?

At present there is no scientific evidence for extraterrestrial life. The complexity of even a single cell suggests that the origins of life may be highly improbable and that it may not have occurred elsewhere even on billions of planets. Life on Earth may be unique, and the fate of life is then in our hands.

Seeding other planetary systems could prevent the study of pristine space but seeding a few hundred new solar systems will secure and propagate life while leaving hundreds of billions of pristine stars for exploration.

${ }^{27}$ E.F. Mallove \& G.L Matloff. 1989. The Starflight Handbook: A Pioneer's Guide to Interstellar Travel. New York, NY: Wiley; J.H. Mauldin. 1992. Prospects for Interstellar Travel (Science and Technology, Vol 80) San Diego, CA: Univelt.

${ }_{28}$ Mautner, op. cit. note 5; Mautner \& Matloff, op. cit. note 6.

${ }^{29}$ Mautner \& Matloff, op. cit. note 6. 
Conclusive proofs of extraterrestrial life could be provided by interstellar probes, but at achievable velocities, this would require millions of years. In the absence of such proof, we need to seed other solar systems to assure that life will indeed exist elsewhere in the universe.

However, the technology to seed space and, eventually, life itself in this Solar System, have finite durations. Should we accept the certain end of our family of gene/ protein life, in order to avoid a small chance of interfering with putative alien life elsewhere?

The chances of interfering with other life-forms can be minimized by targeting young solar systems where life, especially advanced life, would not have yet started. Even if our microbial missions encounter other life, they may merge with local life and generate new biology. In either case, life will benefit.

Biotic ethics concerns first our own family of gene/ protein life. If this family of life is unique to Earth, its fate is our hands. Panbiotic ethics can then motivate us to seed other solar systems to secure life, with cosmic consequences.

\section{Fundamental changes in biology. How far can we transform, but still preserve, life?}

Biology will have to adapt to space. Authors from Tsiolkovsky to Freeman Dyson, and much science fiction, realized that we may need to design new human traits in space. ${ }^{30}$

Resistance to radiation may be achieved by adapting human cells with genes from Deinococcus radiodurans and other microorganisms. Humans in space may need photosynthetic organs to use solar energy directly. They will need to adapt to reduced gravity, possibly reduce body size, develop new limbs for solar sailing and use engineered mechanical organs. Controlling these organs may require modified brains interfaced with computers. Long-distance space travel may require longevity of millennia, and artificial reproduction.

These technologies are developing, but their products still remain gene/protein life. Current research, however, also addresses basic biology itself. Novel proteins incorporate new amino acids for mechanical strength and for extreme conditions. ${ }^{31}$ Correspondingly, DNA may be expanded with new nucleic bases to code for new proteins.

${ }^{30}$ J.W. Valentine. 1985. The Origins of Evolutionary Novelty and Galactic Colonization. In Interstellar Migration and Human Experience. B.R. Finney \& E.M. Jones, eds. Berkeley, CA: University of California Press: 266-276; Hart, op. cit. note 7.

31 J.L. Cleland \& C.S. Craik, eds. 1996. Protein Engineering: Principles and Practice Chichester: Wiley.
These developments can transform the very core of gene/protein life. Is this permitted by ethics that aim to preserve life? They may be allowed if the modified biology retains gene/protein reproduction. For example, the new biochemical components may be related to the natural amino acids and to DNA bases, or propagate otherwise through gene/protein cycles. These fundamental changes still preserve essentially gene/protein life.

However, biological life would be eliminated if humans were replaced by robots. ${ }^{32}$ Although robots can be useful, to preserve biology, control should remain with biological beings. Specifically, control should remain with biological brains that have vested interest to perpetuate organic gene/protein life.

Biocentric ethics aims to propagate life. What does this mean when we can transform life? What is the essence of life that we should propagate? How far can we change, and still preserve, life? Biotechnology can soon turn these questions into actionable, practical choices.

\section{Human survival}

Similar questions apply to human survival. If humans are altered, does humankind still survive? Do we aim to preserve the present human species, or help its evolutionary progress?

Even if humans are altered, we would not become extinct if our genes are preserved and extended in advanced post-humans. This is in fact the natural course of evolution.

Biotic ethics value gene/protein life itself, and panbiotic ethics would favor evolution that helps to secure life. Similarly, if advanced post-human species can better secure life, then biotic ethics would approve continued human evolution.

\section{Biocentric ethics, moral and religious values, purpose and determinism}

By biocentric ethics, actions that secure life are morally good, and actions that threaten life are evil. These principles are ancient: 'I put before you good and evil, life and death. ... choose life'. ${ }^{33}$ This text identifies life as the essential moral good, and death as evil. So do more recent sources such as Schweitzer, ${ }^{34}$ and discussions of panbiotic ethics. $^{35}$

\footnotetext{
${ }^{32}$ I. Aleksander \& P. Barnett. 1983. Reinventing Man: The Robot Becomes Reality. New York, NY: Penguin Books.

${ }^{33}$ Bible, op. cit. note 12.

${ }^{34}$ Schweitzer, op. cit. note 14.

${ }^{35}$ Mautner, op. cit. note 5; Mautner \& Matloff, op. cit. note 6.
} 
By life-centered ethics, self-extinction is the ultimate evil. By these principles, dangers that threaten all life constitute infinite risk. No finite cause can justify an infinite risk/benefit ratio. Therefore, biotic ethics cannot accept even a small danger to all Life.

Conversely, endeavors that secure Life, such as expansion in space, are morally imperative. This endeavor will involve large-scale human collaborations, which require justice, peace, compassion, and truth. Human curiosity, ambition, and intelligence are also needed. These values are, therefore, consistent with biotic ethics.

Life-centered ethics are consistent with both religious and secular principles. In religious terms, a Creator who formed life will also desire its propagation. For secular ethics, life-centered principles suggest a rationally based human purpose and related moral and social values.

Having defined a purpose, can we in fact realize it? Is the future open or pre- determined, and can we control it? We cannot test experimentally if Nature is deterministic, because we can only observe one path of events that unfolds in time and cannot see if alternative paths are possible. However, lacking scientific proof that we can affect the future, we still make plans and often realize them.

Although the future cannot be predicted in detail, we can formulate principles that can guide it. Ultimately, biology will define the possible forms and scope of life, and survival will shape its evolution. These laws made us into a force of life in the universe, and will continue to advance us in the future.

\section{Relations between biocentric, biotic and panbiotic ethics}

Biocentric ethics value living organisms, species, and ecosystems. ${ }^{36}$ More generally, a biotic ethics can be defined that values the core pattern of Life itself, that is, selfpropagation through gene/protein cycles. This can be broadened further to panbiotic ethics, which seek to maximize life in space and time, and to incorporate in Life all the accessible resources. ${ }^{37}$

\footnotetext{
${ }^{36}$ Schweitzer, op. cit. note 14 .

${ }^{37}$ Technically, panbiotic ethics aim to realize the full biotic potential of gene/protein life using the carrying capacity of the universe. (See these terms in J.M. Anderson. 1981. Ecology for the Environmental Sciences: Biosphere, Ecosystems and Man. London: Edward Arnold; M. Began, M. Mortimer \& D.J. Thompson. 1996. Population Ecology: a Unified Study of Animals and Plants. Oxford: Blackwell Science.
}

All life-centered ethics aim to secure our family of gene/ protein life. Traditional biocentric ethics favor the conservation of existing species. Biotic ethics favor the evolution of new life-forms that help to secure gene/ protein life in space. Panbiotic ethics favor the perpetual expansion of life with the continuing divergence of new species.

\section{SUMMARY}

Adapting Life to space will require major biological changes, helped by designed evolution. Our designs will then become self-fulfilling, and we shall need to propagate life deliberately in order to secure our survival. Lifecentered ethics can motivate this quest, secure the future, and shape it with far-reaching, even cosmic, consequences. Therefore life-centered ethics themselves need always to be propagated.

Indeed, judging by observed behavior, the effective purpose of life is self-propagation. Briefly, the selfcontained purpose of life is to live. Being part of life then defines a human purpose, to safeguard and propagate life. This also defines moral values: Acts that support life are good and acts that destroy life are evil.

Life-centered ethics can be supported by scientific insights: the biological unity of all gene/protein life, and the special place of complex life in nature, which precisely permits biology to exist.

Life-centered ethics can be generalized as biotic ethics that value the basic patterns of organic gene/protein life, and as panbiotic ethics that seek to expand life in the universe. The panbiotic objectives can be quantified, to maximize the time-integrated biomass in living matter. To maximize life, we can soon start to settle our Solar System, and to seed with life new solar systems beyond.

The expansion of life will increase biological complexity, diversity and intelligence, leading to new species who can further propagate life in the universe. From the human viewpoint, future life may best enjoy conscious existence, further motivating self-propagation. Indeed, control must always remain with organic gene/protein life that has a vested interest to continue organic life.

Whether future evolution will be designed or natural, selection by survival will always apply: Species that seek to propagate life will survive and species that do not, will perish. Therefore, in a designed future we shall always need to seek survival deliberately, and these life-centered principles will always need to be propagated. 
Ultimately, biology will define the possible forms and scope of life, and survival will shape its evolution. These laws made us into a force of life in the universe, and will continue to advance life in the future.

Given the projections of cosmology, life can expect an immense future. With the powers of intelligence, this future is in our hands. For now, we need to establish ethics that will secure life for future generations. Our descendants may then understand nature more deeply and seek to extend life indefinitely. In that future, our human existence will find a cosmic purpose.

Michael N. Mautner is Research Professor of Chemistry, with research interests and over 160 publications in physical chemistry, astrochemistry and biophysics. In astrobiology, his research showed that microorganisms and plants grow well on extraterrestrial asteroid/meteorite resources. He has also published on scientific aspects of the expansion of life space, and our cosmological future. 